\title{
Implementasi Teknik Latihan Asertif bagi Aktualisasi Diri Konselor
}

\author{
Ayong Lianawati, Cindy Asli Pravesti*, Sutijono, Jahju Hartanti, \\ Nur Indah Jayanti, Noer Vita Isnaeni \\ ${ }^{1}$ Universitas PGRI Adi Buana, Surabaya, Indonesia \\ *Coresponding Author : cindyasli@unipasby.ac.id \\ Dikirim: 02-11-2021; Diterima: 10-12-2021
}

\begin{abstract}
Abstrak: Keberanian mengungkapkan pendapat menjadi capaian dalam mencapai aktualisasi diri konselor. Wujud dari keberanian dalam ungkapan pendapat tersebut adalah sikap asertif. Konselor yang berisikap asertif memiliki harga diri yang kuat dalam melindungi peraturan dan haknya. Untuk itu, tujuan dari penelitian ini mengimplementasikan teknik latihan asertif dalam rangka mencapai aktualisasi diri konselor. Implementasi latihan asertif dilaksanakan melalui kegiatan pengabdian pada masyarakat. Adapun metode kegiatan yang digunakan ialah workshop (webinar) secara online (daring) dengan langkah-langkah, pertama langkah awal (observasi), tahap perencanaan, tahap sosialisasi, dan tahap evaluasi berkelanjutan program. Kegiatan pengabdian pada masyarakat ini diikuti oleh 158 peserta. Hasil yang diperoleh sebesar 54,8\% sangat setuju, 43,2\% setuju, $2 \%$ kurang setuju, $0 \%$ tidak setuju terkait kepuasan manfaat latihan asertif bagi aktualisasi diri konselor. Tercapainya aktualiasasi diri melalui latihan asertif ini telah memberikan kontribusi bagi individu dalam memiliki sikap asertif. Ini dimaksudkan bahwa individu yang memiliki sikap asertif menjadi sikap bagi seorang pemerhati bimbingan dan konseling atau konselor, guna mencapai keberhasilan komprehensif dalam proses pemberian layanan bimbingan dan konseling.
\end{abstract}

Kata Kunci: latihan asertif; aktualisasi diri; konselor

\begin{abstract}
Courage to express opinions is an achievement in achieving counselor selfactualization. The manifestation of courage in the expression of this opinion is an assertive. Counselors who are assertive have strong self-esteem in protecting the rules and their rights. For this reason, the purpose of this study is to implement assertive training techniques in order to achieve counselor self-actualization. The implementation of assertive training is carried out through community service activities. The method of activity used is an online workshop with the following steps, the first step (observation), the planning stage, the socialization stage, and the ongoing evaluation stage of the program. This community service activity was attended by 158 participants. The results obtained are 54,8\% strongly agree, 43,2\% agree, $2 \%$ disagree, $0 \%$ disagree regarding the satisfaction of the benefits of assertive exercise for counselor selfactualization. The achievement of self-actualization through this assertive exercise has contributed to individuals in having an assertive. This means that an individual who has an assertive becomes an attitude for an observer of guidance and counseling or a counselor, in order to achieve comprehensive success in the process of providing guidance and counseling services.
\end{abstract}

Keywords: assertive training; self-actualization; counselor

\section{PENDAHULUAN}

Pada kenyataannya, kecenderungan individu memilih diam saat sedang berkumpul. Seperti ragu-ragu hingga tidak berani berpendapat, menghindari berbicara atau obrolan dengan orang lain, serta tidak memilki ketertarikan dalam terlibat dalam kelompok, dan menutup diri (Fitri et al., 2018). Kepercayaan diri merupakan kemampuan yang dimiliki individu untuk mencapai tujuan yakni beraktualisasi diri 
yang ditemukan seiring dengan perilaku asertif (Zimmerman \& Luecke, 2010). Aktualisasi diri melalui perilaku asertif menjadi dasar percaya diri sebagai karakter pribadi utuh. Individu dengan keterampilan asertif akan menunjukkan komunikasi yang jujur dan efektif dalam meningkatkan kepercayaan diri (Bishop, 2013; Dewantari et al., 2021).

Berdasarkan hasil penelitian di atas bahwa latihan asertif dapat membantu dalam mencapai aktualisasi diri. Latihan asertif merupakan teknik pendekatan behavioral yang memiliki tujuan untuk mengubah perilaku individu menjadi lebih berani asertif dalam berbagai situasi sosial (Corey, 2017). Perilaku dalam situasi sosial atau perilaku sosial menjadi sasaran dalam pelatihan asertif, diantaranya, ketegasan dalam memperkenalkan diri, mengajukan permintaan pada orang lain, mengungkap pendapat, menjaga komunikasi dalam pertemanan (Sommers-Flanagan \& SommersFlanagan, 2015). Sehingga, perilaku asertif tersebut juga akan berdampak pada kemandirian dan tanggung jawab pada diri individu. Perilaku asertif juga memiliki tujuan membantu individu dalam mengungkap perasaan, pendapat, keyakinan, serta sikap tanpa ragu-ragu yang dapay menumbuhkan kepercayaan diri (Susanti, 2016).

Latihan asertif secara sederhana dapat dipahami seperti bersikap tegas. Bersikap tegas merupakan bagian dari keterampilan komunikasi inti (Seaward, 2021). Lebih lanjut, ketegasan dapat membantu individu dalam mengekspresikan diri secara efektif dan dapat memberikan penghormatan dan keyakinan orang lain. Tindak ketegasan membuthkan kerendahan hati yang cukup dan dalam menetapkan Batasan yang sehat (Seaward, 2021). Jika hal tersebut tidak ada, maka perasaan yang akan menjadi korban. Untuk itu, perlu pemahaman bagi individu mengenai perbedaan antara peraturan dan hak. Peraturan berada dalam kajian yang diberlakukan dengan hormat. Sedangkan hak merupakan keistimewaan yang tidak diberikan kepada semua orang.

Mengembangkan latihan asertif berdasar pada kebijaksanaan dalam mengetahui saat mengatakan setuju (ya) dan mengetahui saat mengatakan tidak setuju (tidak). Latihan asertif memberikan keseimbangan dalam kebebasan dan tanggung jawab. Hal ini dapat dilakukan seperti, mengatakan tidak jika benar-benar tidak punya waktu dan gunakan bahasa tubuh yang tegas (berdiri tegak). Latihan asertif dapat memberikan manfaat yang baik dalam memulihkan dan mempertahankan perasaan serta harga diri (Seaward, 2021). Bersikap tegas menjadi sumber daya utama dalam menghilangkan perasaan menjadi korban dan ketidakberdayaan. Sehingga, hidup menjadi lebih seimbang.

Latihan asertif menjadi pilihan dalam membantu konseli (Sommers-Flanagan \& Sommers-Flanagan, 2015). Lebih lanjut, latihan asertif memiliki komponen bagi individu yang mengalami gangguan keterampilan sosial. Sehingga, perilaku asertif harus ada dalam setiap pribadi individu. Sikap asertif merupakan perilaku dan komunikasi yang diarahkan kesediannya dalam membela kebutuhan dan kepentingan individu secara langsung dan terbuka dan di saat yang sama menghormati hal-hal yang penting bagi orang lain (Zimmerman \& Luecke, 2010). Sehingga, individu yang memiliki sikap asertif akan menjaga kebutuhan dan minat diri sendiri serta mengenali kebutuhan dan kepentingan orang lain.

Seorang guru maupun konselor pasti berhadapan dengan berbagai persoalan baik menyangkut peserta didik atau konseli, materi belajar, serta metode belajar (Pramulia et al., 2020). Lebih lanjut, proses belajar menjadi efisien dan efektif jika komponen persoalan tersebut saling mendukung (Andriani \& Wakhudin, 2020). Untuk itu, 
pentingnya pribadi yang asertif memiliki rasa harga diri yang kuat dalam melindungi peraturan dan haknya. Komunikasi yang digunakan dalam sikap asertif menjadi komunikasi terbuka, langsung, dan jujur dengan orang lain. Pribadi yang asertif juga bertanggung jawab atas keputusan dan perilaku serta mengakui kesalahannya. Seseorang dapat bersikap asertif memiliki lingkungan yang mendukung dalam memberikan teladan. Lingkungan mulai dari rumah, sekolah, dan keluarga memberikan teladan yang positif, kemudian juga mengajarkan menghadapi rintangan dan menjadi tegas, serta berkomunikasi yang baik.

Berdasarkan hasil kajian dan survey mengenai sikap asertif yang dimiliki oleh individu ternyata sikap pasif menjadi dominan. Untuk itu, diperlukan pemahaman dan latihan asertif bagi individu. Sikap asertif menjadi sumber kepercayaan diri sebagai karakter pribadi utuh yang sesuai dengan unsur pendidikan karakter. Sehingga, aktualisasi diri individu dapat berkembang sesuai dengan tugas perkembangannya. Maka, program pengabdian masyarakat memberikan pelatihan implementasi teknik latihan asertif untuk meningkatkan aktualisasi diri.

\section{METODE PELAKSANAAN KEGIATAN}

Kegiatan pelatihan ini dilaksanakan secara daring melalui webinar dengan tahapan seperti gambar 1 .

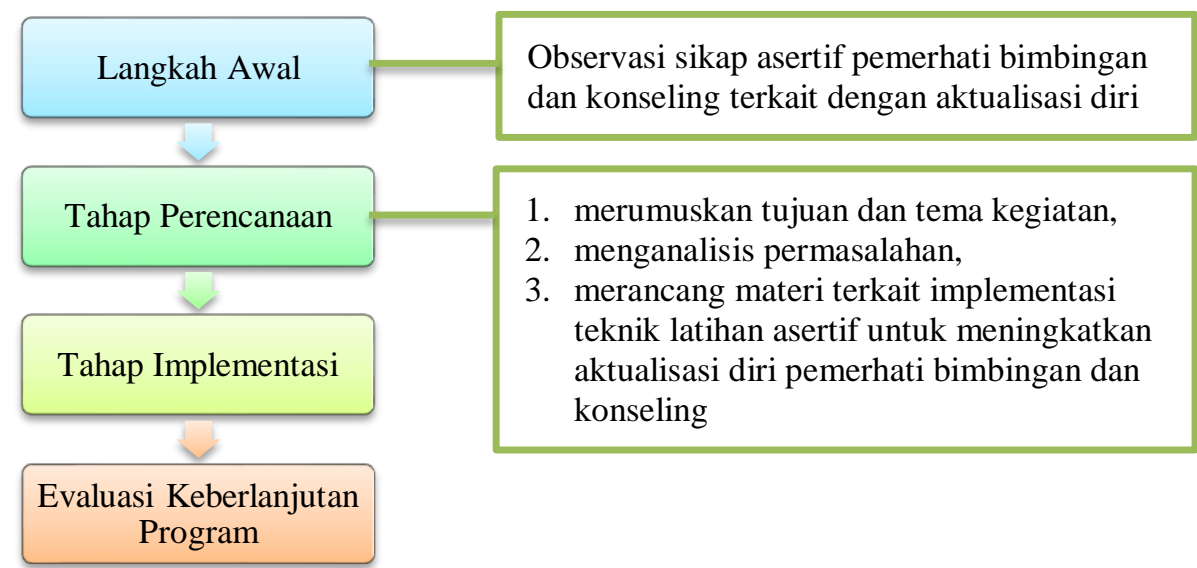

Gambar 1. Metode Alur Pelaksanaan PPM

Upaya kegiatan pengabdian kepada masyarakat menjadi sarana penyegaran bagi guru atau pemerhati bimbingan dan konseling atau konselor guna penguatan pada bidang keilmuan (Syarifuddin et al., 2021). Langkah awal dalam metode pelaksanaan pengabdian pada masyarakat ini merupakan observasi terkait sikap asertif pemerhati bimbingan dan konseling guna aktualisasi diri yang lebih meningkat. Langkah kedua yakni perencanaan dengan melakukan perumusan tujuan serta tema dalam kegiatan, melakukan analisa permasalahan, merancang materi kegiatan implementasi latihan asertif untuk meningkatkan aktualisasi diri konselor. Langkah ketiga yakni implementasi yang dilaksanakan melalui pelatihan secara webinar (daring). Langkah terakhir (keempat) ialah evaluasi keberlajutan dari program kegiatan pengabdian pada masyarakat. 


\section{IMPLEMENTASI KEGIATAN DAN PEMBAHASAN}

Pada alur metode pelaksanaan kegiatan pengabdian pada masyarakat yang menjadi langkah awal ialah pelaksanaan observasi. Observasi dilaksanakan dari tindak lanjut program pengabdian pada masyarakat sebelumnya (semester genap 2020/2021) yang menunjukkan bahwa kegiatan pengabdian pada masyarakat memberikan tanggung jawab, kebenaran, dan kenyataan dalam kehidupan sekolah serta sehari-hari (Pravesti et al., 2021). Adapun yang menjadi sasaran dalam pengabdian pada masyarakat ialah pemerhati bimbingan dan konseling (konselor). Hasil observasi yang didapat bahwa pemerhati bimbingan dan konseling membutuhkan teknik yang mudah untuk dipraktekkan dalam rangka peningkatan aktualisasi diri. Kemudahan praktek dalam kehidupan sehari-hari dari pemerhati bimbingan dan konseling diwujudkan dengan kebebasan mengekspresikan perasaan serta perilaku tanpa mengabaikan hak orang lain. Hal ini seperti, cara berkomunikasi yang diinginkan, mengubah pola pikir yang negatif, menghargai pendapat, menyampaikan penolakan dan kritik, serta cara menciptakan harga diri dan percaya diri (Yulandari, 2018).

Berdasarkan langkah kedua pada alur metode pengabdian pada masyarakat yakni tahap perencanaan. Tahap perencanaan yang pertama ialah merumuskan tujuan dan tema kegiatan. Tujuan dan tema dari kegiatan pengabdian pada masyarakat ini ialah peningkatan aktualisasi diri konselor melalui latihan asertif. Kemudian, tahap perencanaan yang kedua yakni melakukan analisa masalah. Adapun hasil analisa masalah berdasarkan pada survei implementasi latihan asertif bagi pemerhati bimbingan dan konseling diuraiakan pada tabel 1;

Tabel 1. Survei Implementasi Latihan Asertif

\begin{tabular}{llcc}
\hline \multirow{2}{*}{ No } & \multicolumn{1}{c}{ Pertanyaan } & \multicolumn{2}{c}{ \% Implementasi } \\
\cline { 3 - 4 } 1. & $\begin{array}{l}\text { Apakah memahami konsep latihan } \\
\text { asertif? }\end{array}$ & $49,5 \%$ & Belum Pernah \\
\hline 2. & Apakah memahami tujuan latihan asertif? & $46,6 \%$ & $50,5 \%$ \\
\hline 3. & $\begin{array}{l}\text { Apakah anda mengimplementasikan } \\
\text { latihan asertif? }\end{array}$ & $43,7 \%$ & $53,4 \%$ \\
\hline Total Keseluruhan $(\mathrm{n}=103)$ & $48,9 \%$ & $56,3 \%$ \\
\hline
\end{tabular}

Hasil survei di atas telah diketahui bahwa sebesar $51,1 \%$ belum pernah mengimplementasikan latihan asertif. Untuk itu, pemerhati bimbingan dan konseling atau konselor perlu pemahaman dan pelatihan terkait latihan asertif. Adapun materi guna memberikan pemahaman dan pelatihan telah disusun berdasarkan kebutuhan pemerhati bimbingan dan konseling. Rancangan materi seperti pada gambar 2.

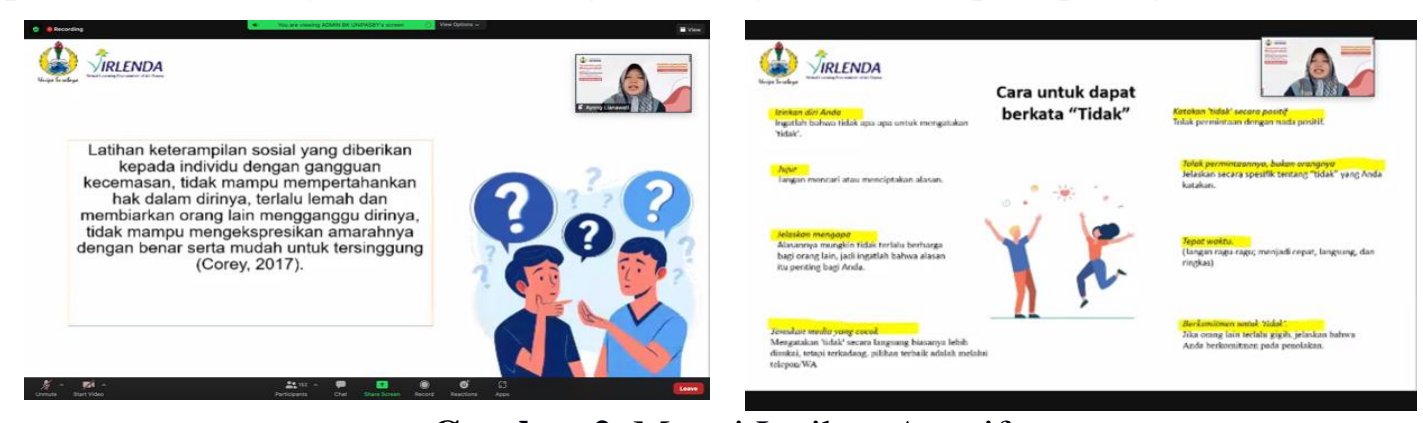

Gambar 2. Materi Latihan Asertif

@ 2021 Bima Abdi (https://jurnal.bimaberilmu.com/index.php/ba-jpm) 
Pada langkah ketiga merupakan tahap implementasi latihan asertif yang diikuti oleh sebanyak 158 peserta. Kehadiran peserta terdokumentasikan dalam gambar 3 .

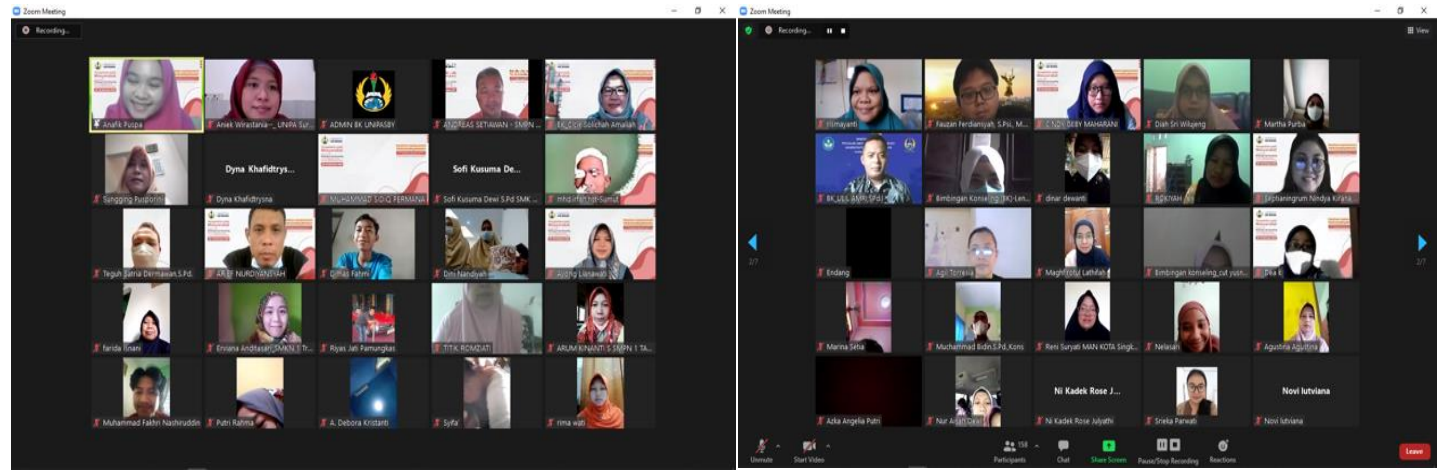

Gambar 3. Antusias Peserta Implementasi

Tahap selanjutnya ialah tahap keempat yakni tahap evaluasi keberlanjutan program. Pada tahap evaluasi keberlanjutan program peserta melakukan praktik latihan asertif secara mandiri guna meningkatkan aktualiasasi diri konselor. Adapun hasil evaluasi keberlanjutan program dicontohkan pada gambar 4.
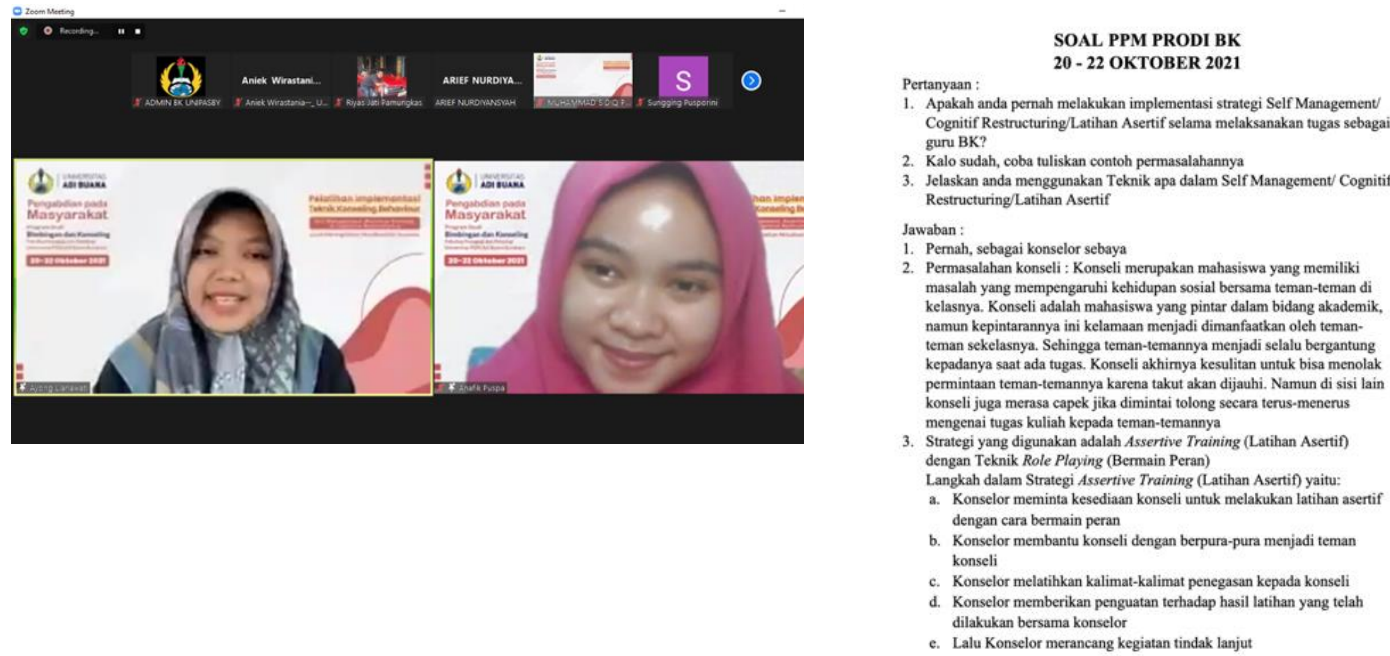

Gambar 4. Hasil Evaluasi Penguasaan Latihan Asertif

Latihan asertif ini bertujuan untuk melatih individu dalam membiasakan berperilaku asertif dalam berhubungan dengan orang lain atau lingkungan sekitarnya. Latihan asertif merupakan salah satu teknik untuk mengarahkan hubungan interpersonal yang terkait dengan ekspresi perasaan, pikiran, emosi serta keiginan dan kebutuhan terbuka, jujur dan tanpa adanya perasaan cemas serta tidak merugikan diri sendiri maupun orang lain. Latihan asertif mengajarkan cara berkomunikasi perubahan pola pikir negatif, menghargai pendapat, menyampaikan penolakan dan kritik, serta menciptakan harga diri dan kepercayaan diri (Yulandari, 2018).

Tujuan latihan asertif (Nursalim, 2005) adalah untuk meningkatkan 4 (empat) kemampuan interpersonal yaitu; a) menyatakan tidak, b) membuat permintaan, c) mengekpresikan perasaan baik positif maupun negatif, d) membuka dan mengakhiri percakapan. Beberapa tujuan penggunaan latihan asertif ini adalah sebagai berikut (Fauzan, 2010); a) mengajarkan individu dalam mengungkapkan dirinya tanpa 
mengalihkan hak orang lain, b) meningkatkan keterampilan sikap sesuai dengan yang diinginkan atau tidak, c) mengajarkan individu merefleksi kepekaanya terhadap perasaan dan hak orang lain, d) meningkatkan kemampuan berekspresi dalam berbagai situasi sosial, e) menghindari kesalahpahaman dalam berkomunikasi, f) menyenangkan orang lain dan menghindari konflik.

Dalam mengimplementasikan latihan asertif, maka pemerhati bimbingan dan konseling mengikuti langkah-langkah pada tabel 2;

Tabel 2. Langkah-Langkah Latihan Asertif

\begin{tabular}{|c|c|c|}
\hline Langkah & Komponen & Isi kegiatan \\
\hline Langkah 1 & Rasional & $\begin{array}{l}\text { Konselor memberikan rasional atau menjelaskan } \\
\text { maksud dan tujuan penggunaan Latihan asertif. } \\
\text { Konselor memberikan gambaran terkait tahapan- } \\
\text { tahapan implementasi strategi. }\end{array}$ \\
\hline Langkah 2 & $\begin{array}{l}\text { Identifikasi kondisi } \\
\text { terkait permasalahan }\end{array}$ & $\begin{array}{l}\text { Konselor meminta konseli mendeskripsikan } \\
\text { dengan terbuka permasalahan yang dihadapi, serta } \\
\text { sikap yang dilakukan atau dipikirkan pada saat } \\
\text { permasalahan timbul. }\end{array}$ \\
\hline Langkah 3 & $\begin{array}{l}\text { Membedakan perilaku } \\
\text { asertif dan tidak asertif, } \\
\text { serta ekplorasi tujuan }\end{array}$ & $\begin{array}{l}\text { Konselor dan konseli membedakan perilaku asertif } \\
\text { dan perilaku tidak asertif, serta menentukan } \\
\text { perubahan perilaku yang diharapkan. }\end{array}$ \\
\hline Langkah 4 & $\begin{array}{l}\text { Bermain peran, } \\
\text { pemberian umpan balik } \\
\text { serta pemberian model } \\
\text { perilaku }\end{array}$ & $\begin{array}{l}\text { - Konseli bermain peran sesuai dengan } \\
\text { permasalahan yang dihadapi. } \\
\text { - } \quad \text { Konselor memberi umpan balik secara verbal. } \\
\text { - } \quad \text { Pemberian model perilaku yang lebih baik. } \\
\text { - } \quad \text { Pemberian penguat positif dan penghargaan. }\end{array}$ \\
\hline Langkah 5 & $\begin{array}{l}\text { Melaksanakan latihan } \\
\text { dan praktik }\end{array}$ & $\begin{array}{l}\text { Konseli menunjukkan perilaku asertif yang sesuai } \\
\text { dengan target perilaku yang diharapkan. }\end{array}$ \\
\hline Langkah 6 & Mengulang latihan & $\begin{array}{l}\text { - Konseli mengulang latihan kembali tanpa bantuan } \\
\text { pembimbing. }\end{array}$ \\
\hline Langkah 7 & $\begin{array}{l}\text { Follow up dan tindak } \\
\text { lanjut }\end{array}$ & $\begin{array}{l}\text { Konselor memberi tugas rumah pada konseli, dan } \\
\text { meminta konseli mempraktekkan perilaku yang } \\
\text { diharapkan, serta memeriksa perilaku target yang } \\
\text { telah dilakukan dalam kehidupan sehari-hari. }\end{array}$ \\
\hline Langkah 8 & Terminasi & - Konselor menghentikan layanan bantuan. \\
\hline
\end{tabular}

Dari uraian di atas, implementasi latihan asertif menjadi teknik yang mudah dipraktekkan dalam kehidupan sehari-hari. Hasil survei awal yang menyebutkan bahwa $51,1 \%$ belum pernah mengimplementasikan latihan asertif, namun kemudian setelah mengikuti pelatihan implementasi latihan asertif menerima manfaat dengan hasil pada tabel 3;

Tabel 3. Survei Manfaat Latihan Asertif

\begin{tabular}{|c|c|c|}
\hline Manfaat & $\%(\mathrm{n}=158)$ & Keterangan \\
\hline Terus tumbuh dan belajar & $80,6 \%$ & \multirow{8}{*}{$\begin{array}{l}\text { Latihan asertif dapat membantu bagi orang- } \\
\text { orang yang (Corey, 2017); } \\
\text { 1. Kesulitan menyatakan perasaan negatif. } \\
\text { 2. Memperlihatkan sikap sopan yang } \\
\text { berlebihan dan mengupayakan orang } \\
\text { lain untuk lebih dulu. } \\
\text { 3. Merasa sulit untuk mengatakan "tidak". } \\
\text { 4. Merasa sulit memberikan respon positif } \\
\text { serta merasa tidak punya hak merasakan } \\
\text { dan memiliki pikiran sendiri. }\end{array}$} \\
\hline Berpikiran terbuka & $71,8 \%$ & \\
\hline Mengetahui hak diri & $59,2 \%$ & \\
\hline Mengatasi kesalahan secara positif & $70 \%$ & \\
\hline Berlatih mendengarkan secara aktif & $79,6 \%$ & \\
\hline Mampu mengekspresika kebutuhan & $61,2 \%$ & \\
\hline Mempertahankan apa yang diyakini & $59,2 \%$ & \\
\hline Memiliki keberanian untuk bermimpi & $64,1 \%$ & \\
\hline
\end{tabular}


Maka, dari tabel 3 dapat dinyatakan bahwa peserta pelatihan yakni pemerhati bimbingan dan konseling telah menerima manfaat latihan asertif. Uraian pada tabel tersebut juga sejalan dengan pernyataan bahwa individu dapat bertindak sesuai dengan kepentingan pribadi dalam bertindak atau berperilaku secara bebas tanpa kecemasan, mengekspresikan perasaan senang dengan keadaanya sebenarnya tanpa mengabaikan hak serta kepentingan orang lain, kemudian mampu menerima kenyataan bahwa diri sendiri telah berperilaku benar dan layak (Willis, 2004).

Untuk itu, kebutuhan akan sikap asertif yang diterima oleh para peserta dalam pelatihan ini telah membawa kepuasaan tersendiri. Adapun hasil survei kepuasan implementasi latihan asertif bagi konselor dalam meningkatkan aktualisasi diri dapat dilihat pada tabel 4;

Tabel 4. Survei Kepuasan Implementasi Latihan Asertif

\begin{tabular}{|c|c|c|c|c|c|}
\hline \multirow[b]{2}{*}{ No } & \multirow[b]{2}{*}{ Pernyataan } & \multicolumn{4}{|c|}{ \% Kepuasan } \\
\hline & & $\begin{array}{l}\text { Sangat } \\
\text { Setuju }\end{array}$ & Setuju & $\begin{array}{l}\text { Kurang } \\
\text { Setuju }\end{array}$ & $\begin{array}{l}\text { Tidak } \\
\text { Setuju }\end{array}$ \\
\hline 1. & $\begin{array}{l}\text { Saya mendapatkan wawasan baru mengenai } \\
\text { latihan asertif }\end{array}$ & $68 \%$ & $32 \%$ & $0 \%$ & $0 \%$ \\
\hline 2. & $\begin{array}{l}\text { Narasumber memberikan pelatihan dengan } \\
\text { detail }\end{array}$ & $64,8 \%$ & $35,2 \%$ & $0 \%$ & $0 \%$ \\
\hline 3. & $\begin{array}{l}\text { Rangkaian kegiatan pelatihan dilaksanakan } \\
\text { dengan efektif dan efisien }\end{array}$ & $51,2 \%$ & $48,8 \%$ & $0 \%$ & $0 \%$ \\
\hline 4. & $\begin{array}{l}\text { Saya antusias selama kegiatan implementasi } \\
\text { latihan asertif berlangsung }\end{array}$ & $35,2 \%$ & $56,8 \%$ & $8 \%$ & $0 \%$ \\
\hline & Total Keseluruhan $(\mathrm{n}=158)$ & $54,8 \%$ & $43,2 \%$ & $2 \%$ & $0 \%$ \\
\hline
\end{tabular}

Berdasarkan tabel 4 dapat dinyatakan bahwa $54,8 \%$ peserta pelatihan sangat setuju dengan pelatihan implementasi latihan asertif bagi konselor yang dapat meningkatkan aktualisasi diri. Hal ini merupakan perwujudan dari keselarasan antara kebutuhan konselor guna mencapai aktualisasi diri dengan materi progam pengabdian masyarakat. Seperti uraian pada Tabel 1 bahwa sebanyak 51,1\% belum pernah mengimplementasikan latihan asertif, kemudian dilaksanakan implementasi latihan asertif yang memberikan manfaat seperti pada tabel 3 .

Latihan asertif merupakan latihan keterampilan sosial yang diberikan kepada individu dengan gangguan kecemasan, tidak mampu mempertahankan hak dalam dirinya, terlalu lemah dan membiarkan orang lain mengganggu dirinya, tidak mampu mengekspresikan amarahnya dengan benar serta mudah untuk tersinggung (Corey, 2017). Prosedur mendasar dalam latihan asertif tidak jauh berbeda dengan beberapa pendekatan perilaku dalam konseling.

Prosedur ini lebih mengutamakan pada tujuan yang spesifik (Osipow et al., 1984), adapun prosedur tersebut ialah pertama, menentukan kesulitan konseli dalam bersikap asertif. Kedua, identifikasi harapan dan keinginan perilaku konseli. Ketiga, menetapkan perilaku konseli yang diharapkan dan tidak. Keempat, membantu konseli untuk membedakan perilaku yang dibutuhkan dan yang tidak dibutuhkan dalam rangka menyelesaikan masalahnya. Kelima, mengungkapkan ide-ide yang tidak rasional, sikap-sikap dan kesalahpahaman dalam pikiran konseli. Keenam, menentukan respon asertif atau sikap yang diperlukan untuk menyelesaikan persoalan (melalui contoh-contoh). Kemudian, ketujuh mengadakan implementasi sikap asertif dan mengulanginya. Kedelapan, melanjutkan latihan sikap asertif. Kesembilan, memberikan tugas kepada konseli guna melancarkan sikap asertif tersebut. 
Selanjutnya yang terakhir kesepuluh, memberikan penguatan terhadap tingkah laku yang diinginkan. Sehingga, latihan sikap asertif menitikberatkan pada individu dalam berkomunikasi yang baik dengan individu lainnya, mengungkapkan yang sedang dialami, serta merasakan keinginannya dengan penuh percaya diri namun tetap menghargai orang lain.

\section{KESIMPULAN}

Implementasi latihan asertif dalam peningkatan aktualisasi diri bagi pemerhati bimbingan dan konseling atau konselor mendapatkan tingkat kepuasan sebesar 54,8\% sangat setuju. Hal ini diartikan bahwa tingkat kejelasan, kepuasan, dan kerbermanfaatan materi pengabadian pada masyarakat dengan tema implementasi latihan asertif dapat diterima oleh pemerhati bimbingan dan konseling atau konselor. Untuk itu, latihan asertif bagi pemerhati bimbingan dan konseling memberikan manfaat bagi individu dalam mengungkapkan keadaan dan keinginannya pada orang lain dengan lebih percaya diri. Sehingga, kemudahan penerapan latihan asertif dalam kehidupan sehari-hari dapat mencapai aktualisasi diri pemerhati bimbingan dan konseling atau konselor. Tercapainya aktualiasasi diri melalui latihan asertif ini telah memberikan kontribusi bagi individu dalam memiliki sikap asertif. Ini dimaksudkan bahwa individu yang memiliki sikap asertif menjadi sikap bagi seorang pemerhati bimbingan dan konseling atau konselor, guna mencapai keberhasilan komprehensif dalam proses pemberian layanan bimbingan dan konseling.

\section{UCAPAN TERIMA KASIH}

Implementasi latihan asertif ini dilaksanakan dalam kegiatan pengabdian pada masyarakat. Kegiatan ini terselenggara dari dukungan Lembaga Penelitian dan Pengabdian Pada Masyarakat (LPPM), Universitas PGRI Adi Buana Surabaya. Dukungan yang diberikan berupa fasilitas sarana dan prasarana guna melengkapi implementasi latihan aserrtif ini. Ucapan terima kasih dalam implementasi latihan asertif juga disampaikan kepada para 158 peserta yang telah bersemangat dari awal kegiatan hingga akhir kegiatan. Sehingga, kelancaran, kesuksesan, kejelasan, kepuasan, dan kebermanfaatan implementasi latihan asertif dapat diwujudkan dengan optimal.

\section{DAFTAR PUSTAKA}

Andriani, A., \& Wakhudin. (2020). Implementasi Pendidikan Karakter Melalui Model Pembelajaran Discovery Learning di Mim Pasir Lor Karanglewas Banyumas. JPM: Jurnal Pengabdian kepada Masyarakat, 1(2), 51-63.

Bishop, S. (2013). Develop Your Assertiveness. Kogan Page Limited.

Corey, G. (2017). Theory and Practice of Counseling and Psychotherapy, Tenth Edition. Cengage Learning.

Dewantari, T., Surya, B. H., \& Bulantika, S. Z. (2021). Group Counseling with Assertive Training Techniques to Self Confidence Adolescents. Jurnal Kependidikan: Jurnal Hasil Penelitian dan Kajian Kepustakaan di Bidang Pendidikan, Pengajaran dan Pembelajaran, 7(1), 35-41. https://doi.org/https://doi.org/10.33394/jk.v7i1.3317 
Fauzan, L. (2010). Makalah Konseptual Assertive Training http://lutfifauzan.wordpress.com/2010/01/12/makalah-konseptualassertivetraining/

Fitri, E., Zola, N., \& Ifdil. (2018). Profil Kepercayaan Diri Remaja serta Faktor-Faktor yang Mempengaruhi. Jurnal Penelitian Pendidikan Indonesia, 4(1), 1-5.

Nursalim, M. (2005). Strategi Konseling. Unesa University Press.

Osipow, S. H., Walsh, W. B., \& Tosi, D. J. (1984). A Survey of Counseling Methods. Dorsey Press.

Pramulia, P., Rachmadtullah, R., Fanani, A., Kusmaharti, D., \& Susiloningsih, W. (2020). Pelaporan Classroom Based Action Research bagi Guru Sekolah Dasar di Kecamatan Sidayu. J-ADIMAS (Jurnal Pengabdian kepada Masyarakat), 8(1), 31-36.

Pravesti, C. A., Lianawati, A., Mufidah, E. F., Muis, T., Sutijono, Arifin, \& Fitriya, P. A. (2021). Peningkatan Kualitas Guru Bimbingan dan Konseling Melalui Penguasaan Teori Realita. Jurnal Pengabdian Pada Masyarakat, 6(3), 731739.

Seaward, B. L. (2021). Essentials of Managing Stress, Fifth Edition. Jones \& Bartlett Learning.

Sommers-Flanagan, J., \& Sommers-Flanagan, R. (2015). Counseling and Psychotherapy Theories in Context and Practice, with Video Resource Center Skills, Strategies, and Techniques. John Wiley \& Sons, Inc.

Susanti, R. H. (2016). Efforts to increase junior high school students' confidencethrough assertive training. COUNS-EDU The International Journal of Counseling and Education, 1(1), 34-40. https://doi.org/DOI: 10.23916/3338.0016.11-i32b

Syarifuddin, Nugroho, P. B., Fadhli, M., Murtalib, Mutmainah, Muchlis, Mikrayanti, Wirahmad, I., Sartika, D., Andang, Mulyadin, E., \& Hadi, A. M. (2021). Sosialisasi Aplikasi Pembelajaran Jarak Jauh dan Pengembangan Bahan Ajar bagi Dosen, Guru, dan Mahasiswa di Era Pandemi Covid-19. Bima Abdi: Jurnal Pengabdian Masyarakat, 1(1), 30-36. https://doi.org/https://doi.org/10.53299/bajpm.v1i1.37

Willis, S. S. (2004). Konseling Individual Teori dan Praktek. Alfabeta.

Yulandari, A. (2018). Efektivitas Layanan Bimbingan Kelompok dengan Teknik Assertive Training untuk Meningkatkan Komunikasi Interpersonal Peserta Didik Kelas XI Ilmu-Ilmu Bahasa (IIB) MAN 1 Bandar Lampung Tahun Pelajaran 2018/2019 Universitas Islam Negeri Raden Intan Lampung]. http://repository.radenintan.ac.id/4745/1/ANITA\%20YULANDARI.pdf.

Zimmerman, C., \& Luecke, R. A. (2010). Asserting Yourself at Work. American Management Association. 